\title{
The cellular infiltrate in Hashimoto's disease and focal lymphocytic thyroiditis
}

\author{
M. HARRIS \\ From the Department of Pathology, University of Bristol
}

SYNOPSIS The lymphoid cells infiltrating the thyroid in three examples of Hashimoto's disease an three examples of focal lymphocytic thyroiditis have been studied by light and electron microscopy? The cell types found were small lymphocytes, plasma cells and plasmablasts, immunoblasts, and celli morphologically intermediate between immunoblasts and small lymphocytes. The infiltrate wașo similar in the two conditions studied and resembled the cell response found in other condition thought to be due to delayed hypersensitivity. It is considered that these similarities support the views that focal lymphocytic thyroiditis is a focal form of Hashimoto's disease and that delayed hypersensitivity is important in the pathogenesis of these conditions.

Infiltration of the thyroid by lymphoid cells in Hashimoto's disease is thought to reflect a delayed hypersensitivity reaction to the thyroid tissue (Lindsay, 1964).

The purpose of this paper is to describe these lymphoid cells in detail and to compare them with the cell mediators found in other examples of delayed hypersensitivity reactions. A comparison is also made with focal lymphocytic thyroiditis since this is regarded by some authorities as a focal form of Hashimoto's disease (Doniach, 1960).

\section{MATERIALS AND METHODS}

Thyroid tissue from three cases of histologically proven Hashimoto's disease and three cases of hyperthyroidism with focal lymphocytic thyroiditis was examined.

Tissue for electron microscopy was obtained from the fresh surgical specimens immediately after excision, cut into $1 \mathrm{~mm}^{3}$ blocks and fixed in ice-cold glutaraldehyde in phosphate buffer at $p \mathbf{H ~} \mathbf{7 \cdot 2}$ for two hours, postfixed in buffered osmium tetroxide, and embedded in Epon (Luft, 1961). Sections were cut on a Reichert ultratome, stained with uranyl acetate and lead citrate and examined in a Hitachi HS7S electron microscope.

In all cases representative blocks were embedded in paraffin wax, and sections stained by haematoxylin and eosin and methyl green-pyronin were examined.

For the purposes of this study focal lymphocytic thyroiditis was defined as multiple collections of lymphoid cells in the interstitial tissue throughout the gland. Askanazy cell metaplasia, lymphoid follicle formation, and fibrosis were not considered to be essential features. In selecting areas for electron microscopy germinal centres, if present, were avoided.

Received for publication 2 October 1968.
RESULTS

The types of infiltrating cells were similar in alf the specimens examined whether examples of Hashimoto's disease or of focal lymphocytiê thyroiditis.

LIGHT MICROSCOPY Three cell types were identifie产 (Figs. 1 and 2), namely, small lymphocytes, plasma cells, and large lymphocytes with basophilic pyroninophilic cytoplasm, and vesicular, sometimes infolded nuclei.

ELECTRON MICROSCOPY The cell types identifie were small lymphocytes, large lymphocytes, an plasma cells.

Small lymphocytes These cells (Fig. 3) were 4 to $6.5 \mu$ in diameter. Their cytoplasm varied in amount but was always relatively scanty and in contained abundant single, free ribosomes in rather electron-opaque hyaloplasm. Endoplasmie reticulum was very sparse, the Golgi apparatus was small and only seen occasionally, and there weres few mitochondria. Nuclear chromatin was coarsely condensed and a nucleolus was rarely seen.

Large lymphocytes The cell diameters varie $\tilde{\Phi}^{\circ}$ from 7.8 to $12.6 \mu$. Cytoplasm was greater inf amount than in the small lymphocytes and waso sometimes abundant; free ribosomes were plentifu. and arranged mainly as polyribosomes in aro electronlucent hyaloplasm. Although better deve $\Phi_{0}^{\circ}$ loped than in the small lymphocytes, endoplasmig reticulum was still scanty and consisted of narrow 


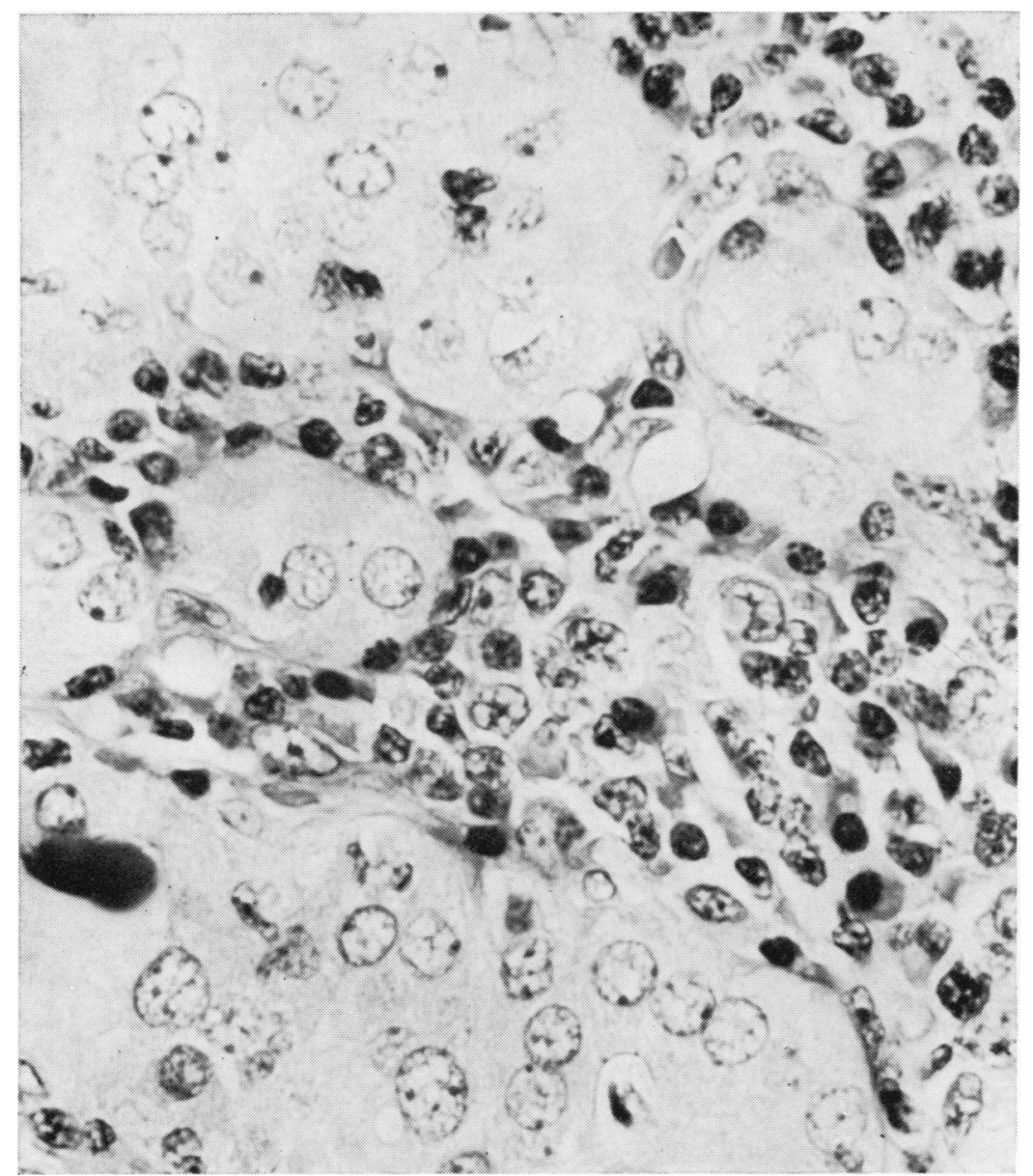

FIG. 1. Hashimoto's disease; a group of mononuclear cells is present between small follicles lined by Askanazy cells. The infiltrating cells comprise plasma cells, a few small lymphocytes, and, near the centre of the field, four large lymphocytes with vesicular, infolded nuclei and basophilic cytoplasm. Haematoxylin and $\operatorname{eosin} \times 720$. double strands irregularly studded with ribosomes. Mitochondria were present in moderate numbers and the Golgi apparatus was often seen to be well developed. Nuclear chromatin was less coarsely condensed than in the small lymphocytes and a nucleolus was often present. These cells (Fig. 4) were considered to be identical with the cells termed immunoblasts, large pyroninophilic cells, haemocytoblasts, etc, by various authors.

A number of cells resembled those just described except that they tended to be smaller (6 to $7.6 \mu$ diameter) and their ribosomes were variable in number and were either arranged mainly as single free particles or as a mixture of varying proportions of polyribosomes and single ribosomes (Figure 5). In many respects they resembled cells described by de Petris, Karlsbad, Pernis, and Turk (1966) in lymph nodes draining areas of contact sensitivity and considered by them to be intermediate between immunoblasts and small lymphocytes.
Plasma cells Numerous morphologically typical plasma cells were seen and will not be described further (Figure 6). In addition there were a number of cells which appeared to be morphologically intermediate between immunoblasts and mature plasma cells. These cells contained more rough endoplasmic reticulum than immunoblasts and as the amount increased it became progressively more orientated into parallel arrays (Figures 6, 7, and 8). They appear to correspond to the cells termed plasmablasts and described in lymph nodes draining homografts (André-Schwartz, 1964) and in nodes draining an area of contact sensitivity (de Petris et al, 1966).

\section{DISCUSSION}

The mechanism of tissue damage in human and experimental lymphocytic thyroiditis is uncertain. The demonstration of circulating autoantibodies in Hashimoto's disease (Roitt, Doniach, Campbell, 


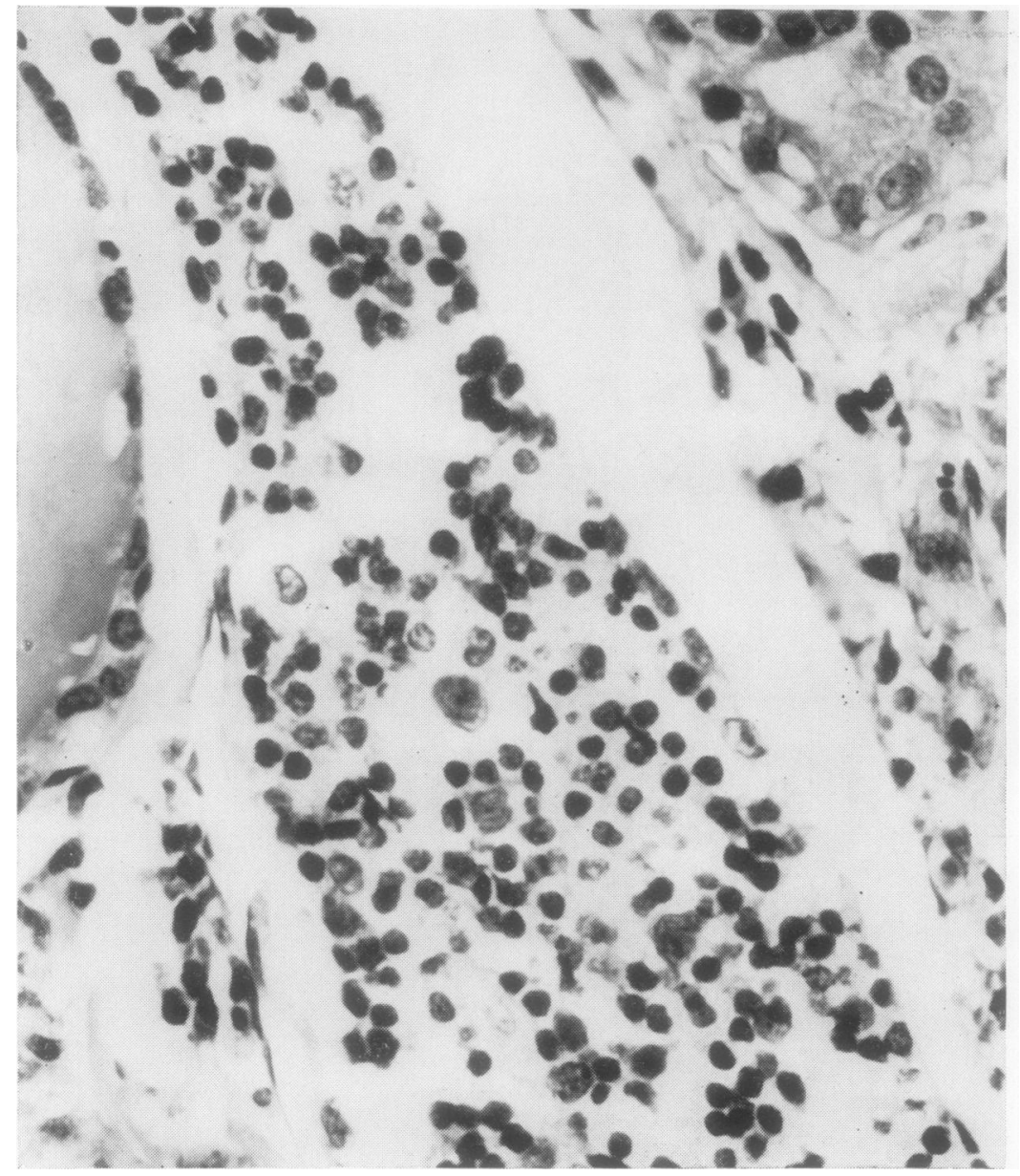

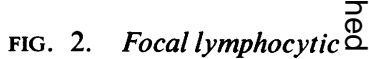
thyroiditis. In this field the infiltrating cells are mostly small lymphocytes with occasional plasma cells. Also present, in the centre and lower half of the field, are four large lymphocytes. Haematoxylin and eosin $\times 720$.

and Hudson, 1956; Witebsky, Rose, Terplan, Paine, and Egan, 1957) appeared at first to provide a satisfactory explanation and experiments in vitro with trypsinized monolayer cultures of thyroid cells indicated that Hashimoto serum was cytotoxic (Pulvertaft, Doniach, Roitt, and Hudson, 1959). The cytotoxic component was subsequently shown to be identical with complement-fixing thyroid autoantibody (Forbes, Roitt, Doniach, and Solomon, 1962). However, doubts about the significance of circulating antibodies in the pathogenesis of Hashimoto's disease arose when it became apparent that the antibodies had no adverse effect on monolayer tissue cultures which had not been pretreated with trypsin nor on thyroid fragments in organ culture (Roitt, Jones, and Doniach, 1962; Irvine, 1962).

In experimental autoimmune thyroiditis further difficulties arose when it was shown that the degree of thyroid damage correlated better with delayed 0 hypersensitivity skin tests than with levels of cir- $D$ culating autoantibody (McMaster, Lerner, and Exum, 1961; Miescher, Gorstein, Benacerraf, and Gell, 1961), and it has been demonstrated that ${ }^{\circ}$ the production of delayed hypersensitivity without $\mathbb{\sim}$ antibody formation by immunizing guinea pigs with $\mathcal{C}^{N}$ picrylated homologous thyroglobulin causes thyroiditis (Meischer et al, 1961). Furthermore, attemptso to transfer thyroiditis passively by injecting serum $\bar{\varnothing}$ from sensitized animals into normal animals have $\stackrel{?}{+}$ failed (Rose, Kite, and Doebblers, 1961) although 0 success has been claimed by transferring lymph node $\stackrel{\vec{O}}{\vec{P}}$ cells from sensitized guinea pigs (Felix-Davies and $\stackrel{\odot}{\circ}$ Waksman, 1961; McMaster and Lerner, 1967).

It seems clear that circulating autoantibodies $\sigma$ cannot be the sole factor in the pathogenesis of 


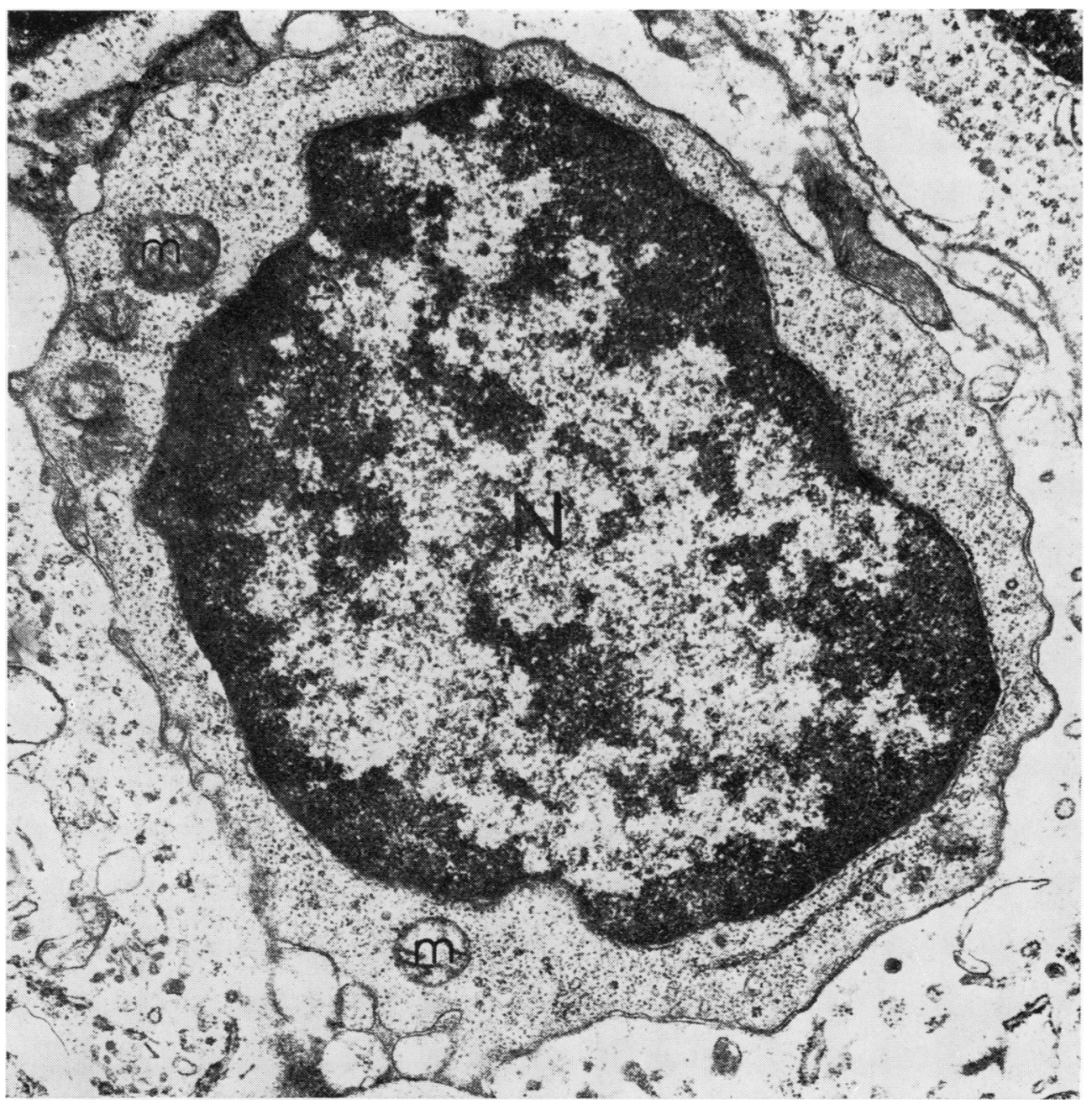

naturally occurring lymphocytic thyroiditis or its experimental counterpart. Roitt et al (1962) have suggested that the antibodies can act only on cells whose surface membranes have first been damaged and that this damage may be caused by sensitized lymphoid cells infiltrating the thyroid.

In view of their apparent importance it is surprising that the nature of the infiltrating cells in Hashimoto's disease has not received more attention. In most histological accounts they are described as lymphocytes and plasma cells with no further qualification and Hazard (1955) referred to them as being of normal 'adult' type. Ultrastructural studies of Hashimoto's disease are few. Irvine and Muir (1963) examined four examples by electron microscopy but they were mainly concerned with epithelial cell and basement membrane changes, and the lymphoid cells were not studied in detail although it was observed that lymphocytes were frequently found within the follicular basement membranes in intimate relationship with the epithelial cells. Binet, Gennes, and Decourt (1963), in a study of two cases of Hashimoto's disease, were exclusively concerned with the nature of the infiltrating lymphoid cells 


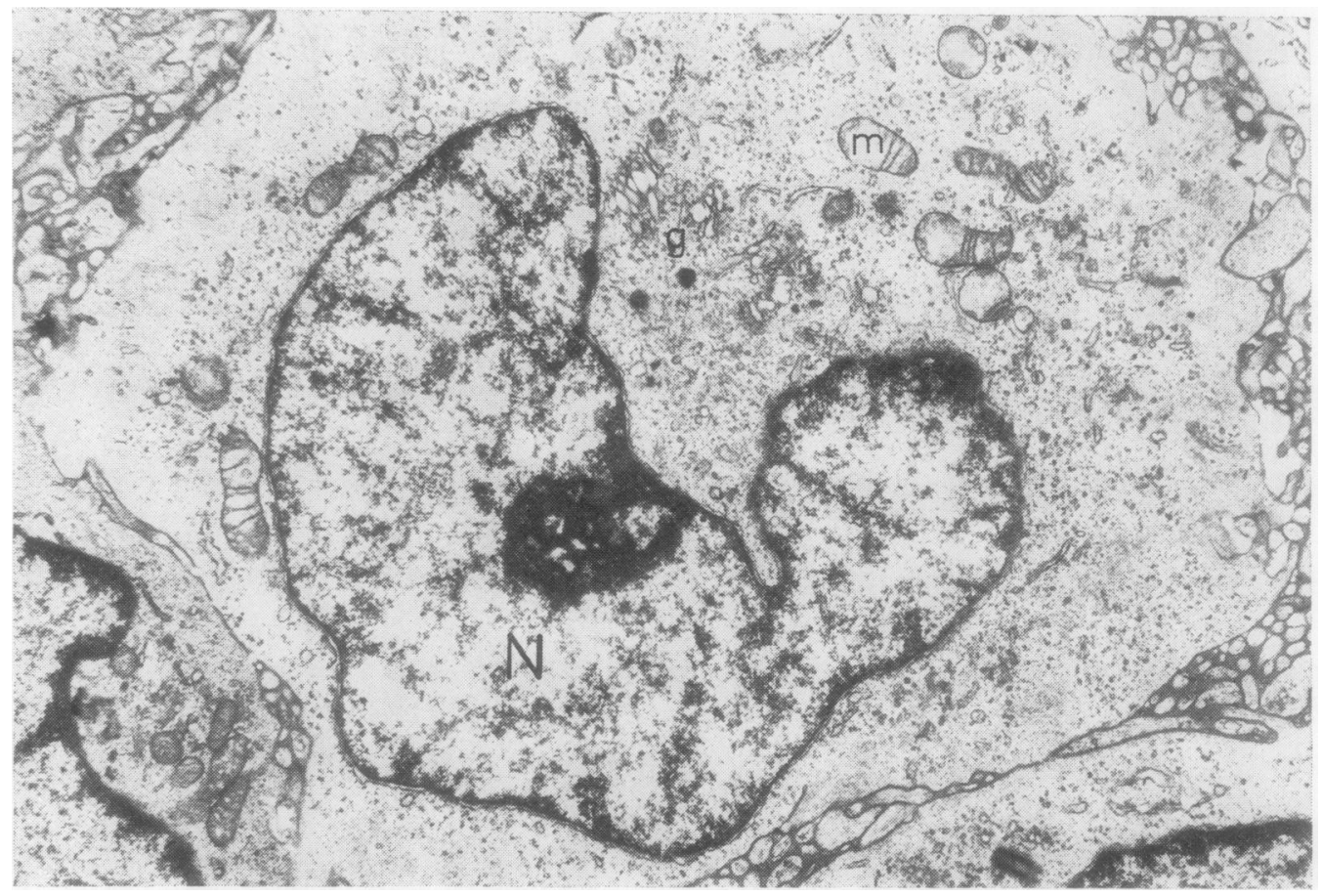

FIG. 4. Large lymphocyte (immunoblast). The nucleus $(\mathrm{N})$ is infolded and the nuclear chromatin is finely dispersed; a nucleolus is present. The cytoplasm contains numerous polyribosomes, scattered short strands of endoplasmic reticulum, several mitochondria $(\mathrm{m})$, and a large Golgi apparatus (g). Uranyl acetate and lead citrate $\times 10,000$.

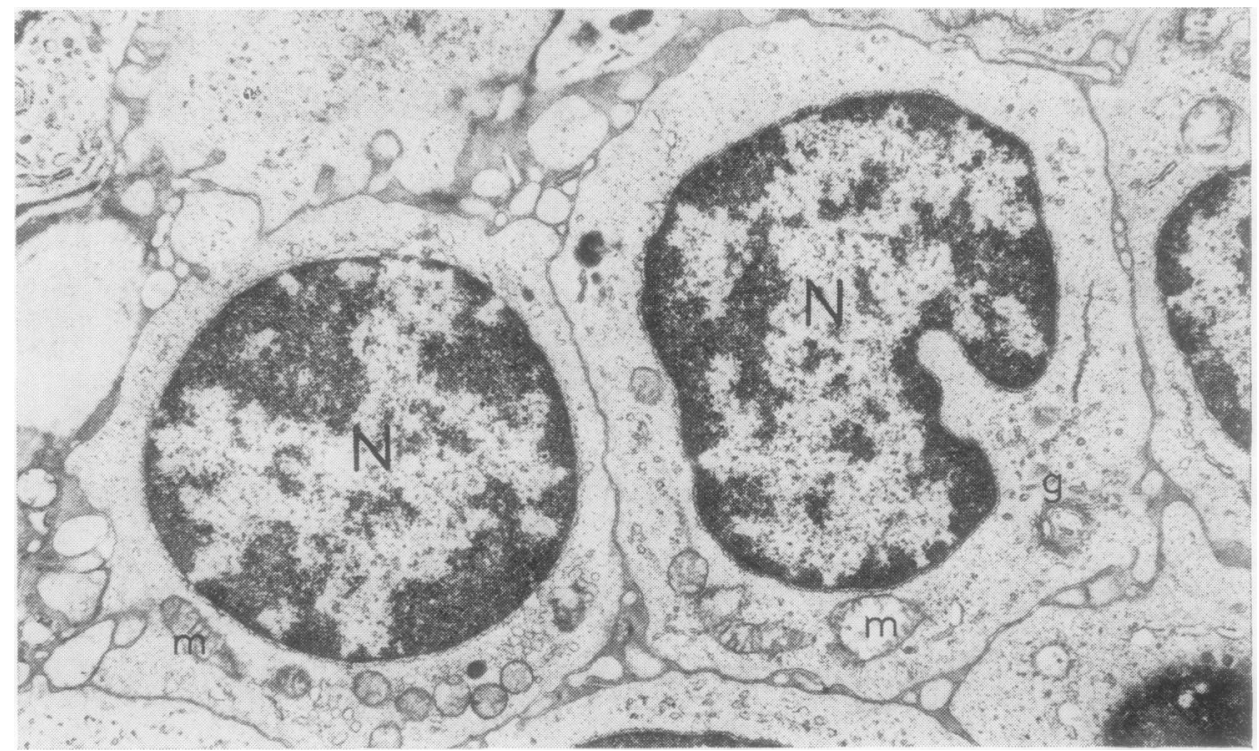

FIG. 5. Two intermediate lymphocytes. The nuclei are similar to the nucleus of a small lymphocyte but the cells are larger, cytoplasm is more plentiful, and there are some polyribosomes as well as numerous single ribosomes. The Golgi apparatus (g) is well developed in the larger cell. Uranyl acetate and lead citrate $\times 10,000$. 


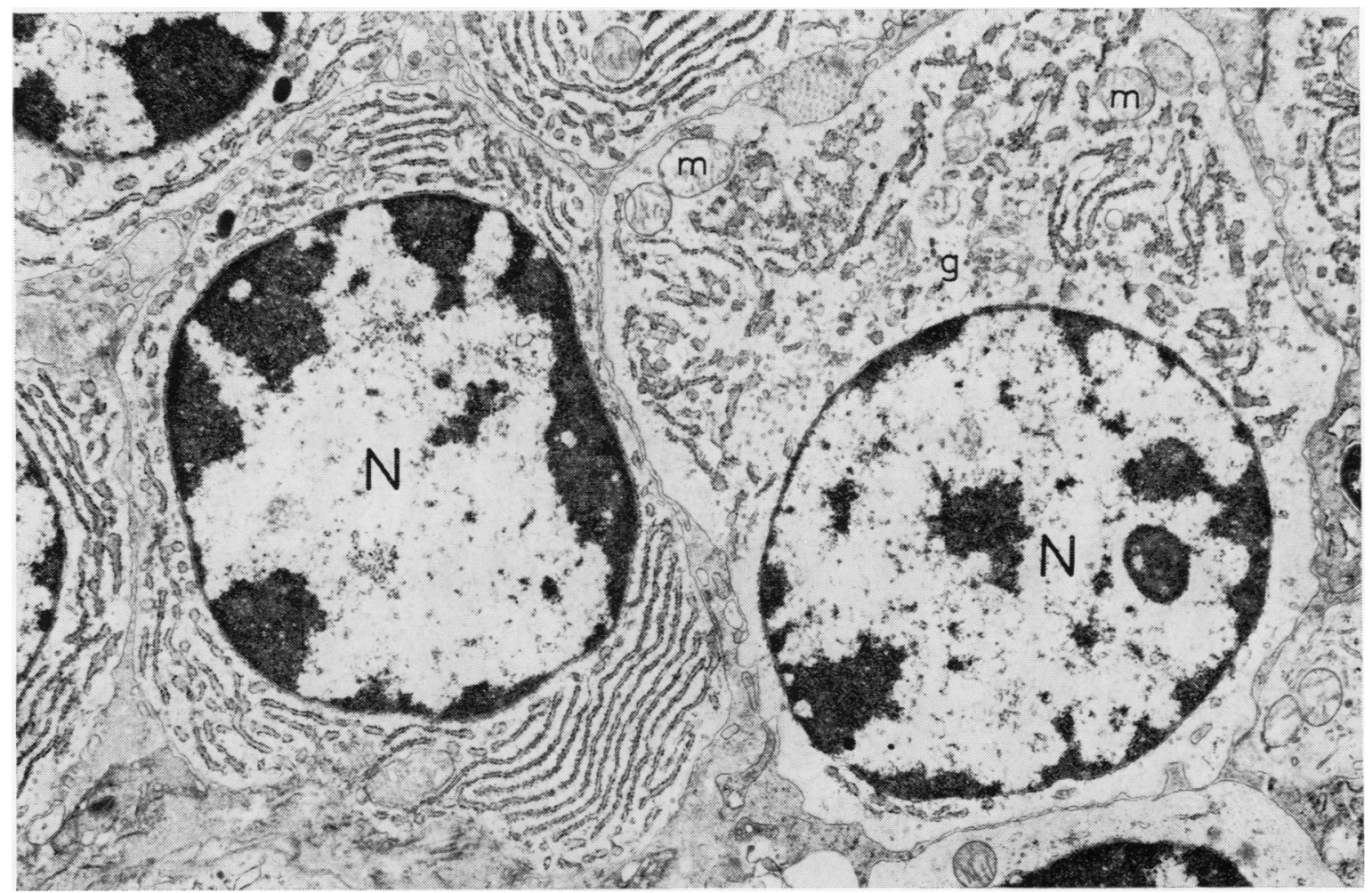

FIG. 6. The cell on the left is a mature plasma cell with abundant rough endoplasmic reticulum arranged in parallel arrays. The cell on the right is considered to be a plasmablast; it contains a moderate amount of rough endoplasmic reticulum and a large Golgi apparatus. Uranyl acetate and lead citrate $\times 10,000$.

and described three cell types, namely, lymphocytes, plasma cells, and basophilic histioflytes like those found in 'retarded reactions to grafts'. The latter had a large Golgi apparatus, numerous cytoplasmic ribosomes, and no ergastoplasm.

No electron microscopic studies of focal lymphocytic thyroiditis have been reported.

In the present study the infiltrating lymphoid cells were similar in Hashimoto's disease and focal lymphocytic thyroiditis and comprised small lymphocytes, plasma cells and plasmablasts, immunoblasts, and cells morphologically intermediate between immunoblasts and small lymphocytes, findings which are in general agreement with those of Binet et al (1963) in Hashimoto's disease.

The similarity of the cellular infiltrate in Hashimoto's disease and focal lymphocytic thyroiditis appears to support the view that the two conditions are essentially similar in pathogenesis, a similarity which has previously been commented on with regard to the epithelial changes in the two conditions and the correlation of focal lymphocytic thyroiditis with the occurrence of circulating antibodies of similar type to those found in Hashimoto's disease (Senhauser, 1964).

The infiltrating cells described here are of the same types as those found infiltrating allografts undergoing unmodified rejection (Porter, Joseph, Rendall, Stolinski, Hoehn, and Calne, 1964), and in lymph nodes draining allografts (André-Schwartz, 1964) and areas of contact sensitivity (de Petris et al, 1966). This resemblance, particularly that between grafts undergoing rejection and thyroids that are affected by lymphocytic thyroiditis, is suggestive of a basic similarity between the various conditions and is considered to support the concept of the fundamental importance of cell-mediated immunity in the pathogenesis of Hashimoto's disease and focal lymphocytic thyroiditis.

I should like to thank Dr A. C. Hunt for his advice and encouragement, Mr E. Wheeler and Miss A. Cross for their expert technical assistance, and $\mathrm{Mr} \mathrm{C}$. Jeal for preparing the photomicrographs. 


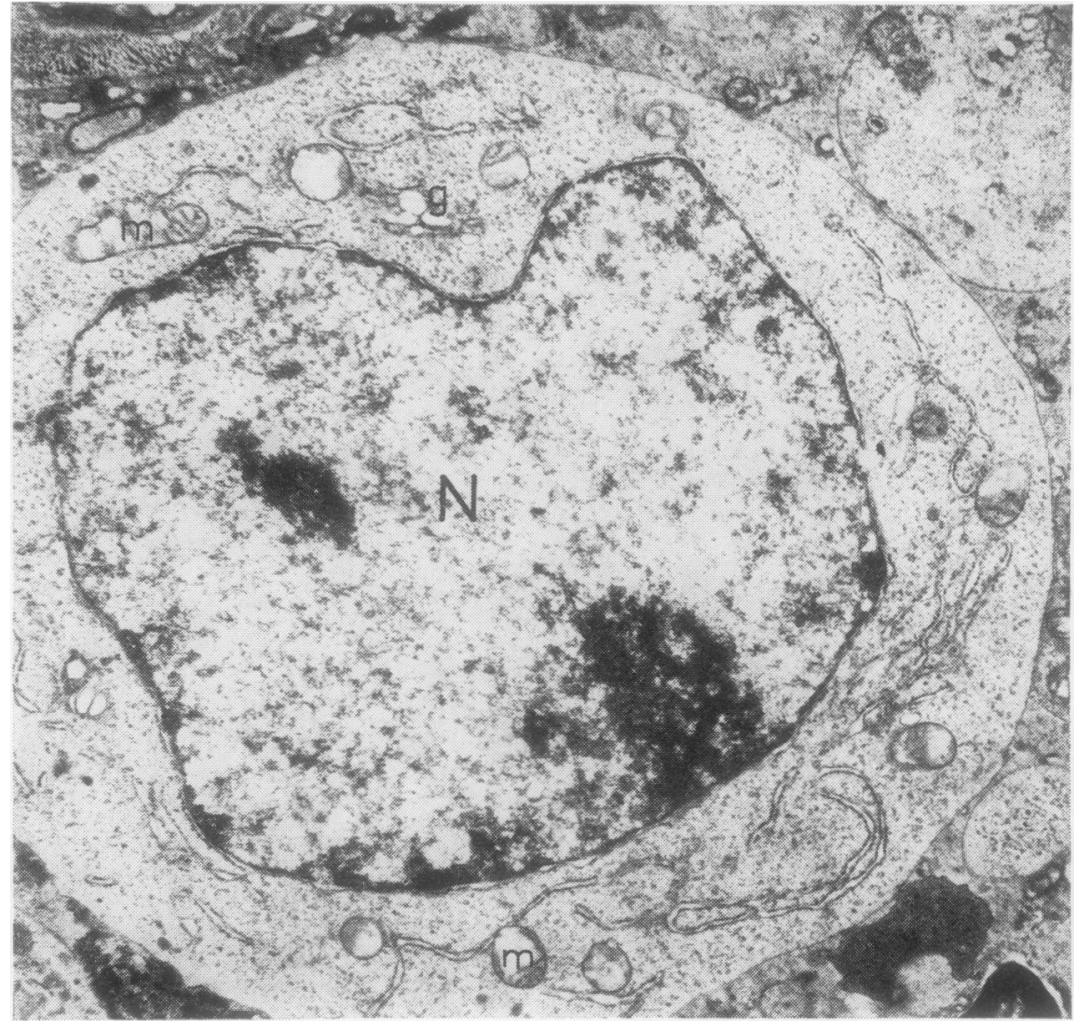

FIG. 7 .

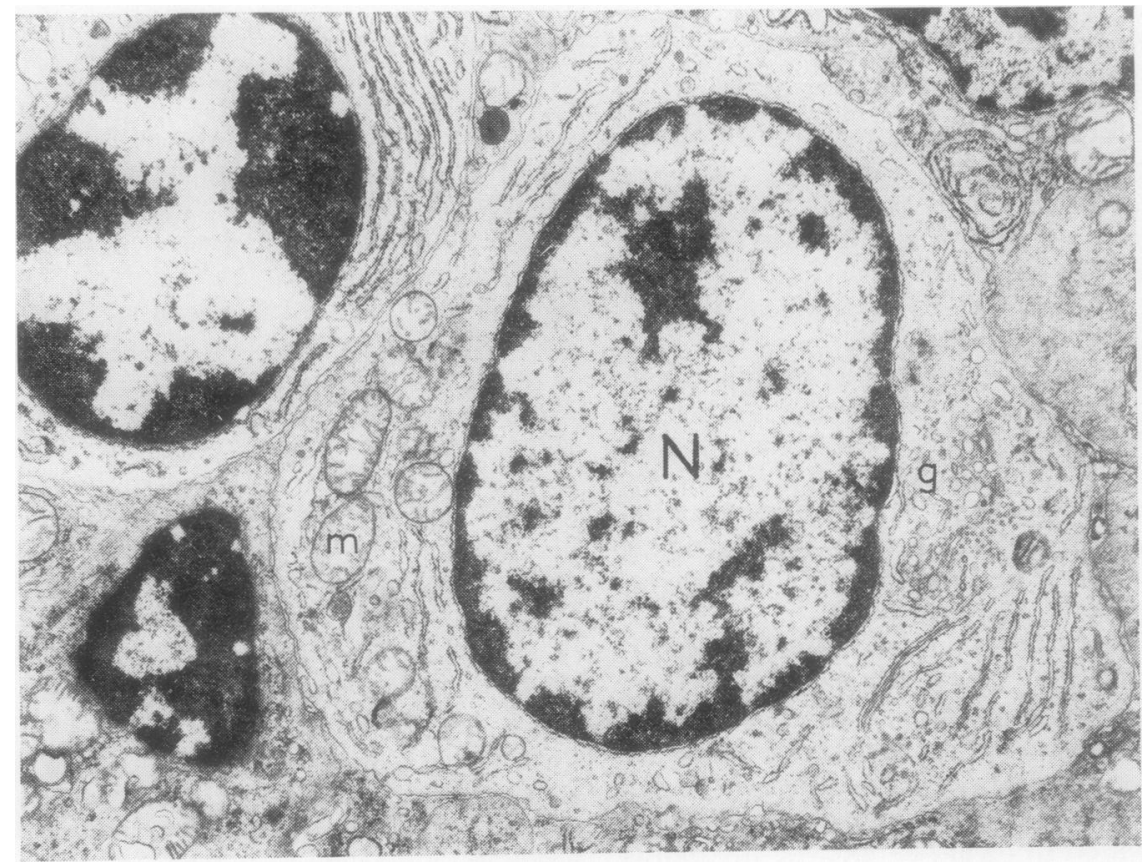

Plasmablast

The nuclear character-

istics are intermediate

between those of a mature

plasma cell and an

immunoblast. The

cytoplasm contains a

moderate amount of rough

endoplasmic reticulum

showing some organization

into parallel arrays. Part

of a mature plasma cell is

seen in the top left corner.

Uranyl acetate and lead

citrate $\times 10,000$.

FIG. 8. 


\section{REFERENCES}

André-Schwartz, J. (1964). Blood, 24, 113.

Binet, J. L., Gennes, J. L. de, and Decourt, J. (1963). Rev. franc. Etud. clin. biol., 8, 1011.

Doniach, I. (1960). In Recent Advances in Pathology, 7th. Ed.,edited by C. V. Harrison, p. 242. Churchill, London.

Felix-Davies, D., and Waksman, B.H. (1961). Arthr. and Rheum., 4, 416.

Forbes, I. J., Roitt, I. M., Doniach, D., and Solomon, I. L. (1962). J. clin. Invest., 41, 997.

Hazard, J. B. (1955). Amer. J. clin. Path., 25, 399.

Irvine, W. J. (1962). Brit. med. J., 1, 1444.

- , and Muir, A. R. (1963). Quart. J. exp. Physiol., 48, 13.

Lindsay, S. (1964). In The Thyroid Gland, vol. 2, edited by R. PittRivers and W. R. Trotter, p. 246. Butterworths, London.

Luft, J. H. (1961). J. biophys. biochem. Cytol., 9, 409.

McMaster, P. R. B., Lerner, E. M., and Exum, E. (1961). J. exp. Med., 113, 611 .

, and Lerner, E. M., II (1967). J. Immunol., 99, 208.

Miescher, P., Gorstein, F., Benacerraf, B., and Gell, P. G. H. (1961). Proc. Soc. exp. Biol. (N. Y.), 107, 12.
Petris, S. de, Karlsbad, G., Pernis, B., and Turk, J. L. (1966). Int. Arch. Allergy, 29, 112

Porter, K. A., Joseph, N. H., Rendall, J. M., Stolinski, C., Hoehn, R. J., and Calne, R. Y. (1964). Lab. Invest., 13, 1080.

Pulvertaft, R. J. V., Doniach, D., Roitt, I. M., and Hudson, R. V. (1959). Lancet, 2, 214.

Roitt, I. M., Doniach, D., Cambell, P. N., and Hudson, R. V. (1956). Ibid., 2, 820.

- Jones, H. E. H., and Doniach, Deborah (1962). In Mechanism of Cell and Tissue Damage produced by Immune Reactions: 2nd International Symposium on Immunopathology, 1961, edited by $\mathbf{P}$. Graber and P. Miescher, p. 174. Schwabe, Basel and Stuttgart.

Rose, N. R., Kite, J. H., Jr., and Doebbler, Thelma K. (1962). In Ibid., p. 161.

Senhauser, D. A. (1964). In The Thyroid, International Academy of Pathology Monograph, Vol. 5, edited by J. Beach Hazard and D. E. Smith, p. 167. Williams and Wilkins, Baltimore.

Witebsky, E., Rose, N. R., Terplan, K., Paine, J. R., and Egan, R. W. 1957). J. Amer. med. Ass., 164, 1439. 